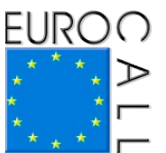

\title{
YELL/TELL: online community platform for teacher professional development
}

\author{
Ivana Marenzi ${ }^{1}$, Maria Bortoluzzi ${ }^{2}$, and Rishita Kalyani ${ }^{3}$
}

\begin{abstract}
The community platform Young/Teen English Language Learners (YELL/ TELL), as mentioned by Bortoluzzi and Marenzi (2014) was "developed to respond to the needs of collaboration and sharing among trainee teachers, school teachers, teacher trainers and researchers in the field of language learning for English [as a Foreign or Second Language (FL/SL)]" (p.182). The current study focuses on ethnographic observation and data gathered during a workshop for professional development organised for experienced teachers. We compare the evidence of the teachers' actions, with the analysis of their perception about their professional use of the online environment and their critical reflection about the experience.
\end{abstract}

Keywords: teacher professional development, lifelong learning, collaboration, evaluation-driven approach.

\section{Introduction}

The social community YELL/TELL, supported by the LearnWeb ${ }^{4}$ social platform, has the aim of encouraging professional collaboration among teachers of different school levels and backgrounds. Lifelong learning and peer-teacher education are promoted on the basis of sharing resources and commenting and reflecting on them in the spirit of co-construction of knowledge through open-educational practices and resources for teaching English as a FL/SL.

This paper is based on an ethnographic observation and qualitative study of the activities carried out in the online community during a blended professional development workshop for experienced school teachers in Italy. The research

\footnotetext{
1. Leibniz University of Hannover, Hannover, Germany; marenzi@L3S.de

2. University of Udine, Udine, Italy; maria.bortoluzzi@uniud.it

3. Leibniz University of Hannover, Hannover; kalyani@L3S.de

4. http://learnweb.13s.uni-hannover.de
}

How to cite this article: Marenzi, I., Bortoluzzi, M., \& Kalyani, R. (2016). YELL/TELL: online community platform for teacher professional development. In S. Papadima-Sophocleous, L. Bradley, \& S. Thouësny (Eds), CALL communities and culture - short papers from EUROCALL 2016 (pp. 307-312). Research-publishing.net. https://doi.org/10.14705/rpnet.2016. eurocall2016.580 
aim is two-fold: (1) investigating how a group of experienced teachers perceive the participation in a professional online community for their professional development, and (2) identifying the affordances of the platform that enhance professional development and improve on the system design.

The study followed the progress of 16 experienced teachers of primary and lower secondary schools during a blended workshop in which the current version of the platform was used to share open access resources and practices, collaborate online and improve on the professional digital skills of searching, selecting, annotating, customising and uploading online resources for English language learning and plurilingualism. The evidence of the teachers' actions within the online environment (logs) were analysed in context along with their discussions about the use of the system and their critical reflection on the experience (comments on the forum and the final questionnaire).

\section{Method}

\subsection{The online platform and community}

The YELL/TELL community platform allows users to share and collaboratively work on resources collected from the web or teacher-generated; resources can be bookmarked, tagged, rated, and discussed by all users who join the different interest groups (Marenzi \& Zerr, 2012). Users can create folders "to bundle resources that belong to the same learning context, [... hence,] collaboratively identify the best learning resources for specific learning domains" (Abel, Marenzi, Nejdl, \& Zerr, 2009, p. 158; see also Bortoluzzi \& Marenzi, 2014). Different groups of users have been involved in the co-design of the platform (Wang \& Hannafin, 2005) from the start (2012), which allows us to carry out throughout the years an iterative evaluation-driven design-based research approach (Marenzi, 2014; Mirijamdotter, Somerville, \& Holst, 2006).

The online community supported by the platform is an inclusive, boundarycrossing professional community used for pre-service, in service and lifelong language teacher education for teachers of nursery, primary and secondary schools. Participants also include teacher educators, university lecturers and computer developers. The community was developed within a flexible socio-constructivist framework as a technology-supported community to contribute to the quality of the teaching profession "by encouraging collaboration and knowledge exchange" 
(Vuorikari et al., 2012, p. 7), to multiliteracy for teachers (Cope \& Kalantzis, 2009) and to enhancing reflection on practice and theory (Edge, 2011).

\subsection{The blended in-service professional development workshop}

The workshop was organised in Pordenone (Italy) and lasted from September to December 2015 for a total of 14 contact hours and tasks for individual online work. Participants were primary and lower secondary school experienced teachers and had very diversified digital skills (from beginners to competent). None of them had ever used the YELL/TELL platform before and the majority were new to digital assistance as a teaching aid. Tasks were designed to get the teachers to do handson work: post materials online, share resources and teaching experiences, discuss teaching practices and the affordances of the platform.

The general aim of the workshop was to reflect on online collaboration for teaching and plurilingual education. From the technical point of view, the research goal was to collect information about teachers' online practices (such as searching, selecting, annotating and customising online resources) and improve on the system interface in support of teaching scenarios.

\subsection{Data analysis}

The data gathered is both hard evidence of actions (logs) and qualitative ethnographic observation as well as qualitative evaluation in context (forum participation, task completion and final questionnaire). In fact, we found a contrast between these two sets of data: whereas the first (1. below) would point towards a rather limited use of the platform, the second (2. below) yields a rich, involved and personalised use of the platform.

1. Activity logs were used to study the search behaviour: how teachers refined their search queries, whether they liked the resource pool returned by the system and whether they encountered some problems while working with the system. A quantitative analysis of the logs showed that teachers issued 840 search queries across the search types Image, Web and Video. Teachers uploaded 262 resources out of which $66 \%$ from their personal workstation and $34 \%$ added through searching on the platform. $30 \%$ of the resources added through search were found in the YELL/TELL platform (not on the Web) as they had been previously added by other users, and were appreciated by the teachers as valuable to be reused in their learning/ teaching context. We know from the feedback questionnaires (2. below) 
that one of the reasons why several teachers were more inclined to share resources from their own desktop was that they felt more confident while sharing a familiar resource, because they had already used and tested it in their teaching practice. Search logs show that sometimes teachers searched for the same query multiple times by either refining the search query itself or by using various search filters. Based on the logs analysis, a few improvements were suggested, and a questionnaire was designed to investigate the observed patterns better.

2. Forum participation and task completion demonstrated the group and individual commitment in using the platform and its affordances: experienced teachers appreciated to be part of a community of likeminded people with whom they could share resources, practices and discuss problems. They praised the fact that resources they can find on the platform are already qualitatively selected and organised by teachers like them and educational experts. They discussed how to tag and annotate resources collaboratively in order to sort and find resources easily, suggesting that a more professionally related tagging system should be put in place. Teachers appreciated the social aspect of the online community and the ease with which it is possible to share and collaborate through commenting, discussing in the forum and creating documents collaboratively.

\section{Discussion}

On the one hand, the hard evidence of logs is limited in range and shows repetitive or incomplete actions: teachers searched for resources, but then uploaded new ones mainly from their desktop; and some uploaded many times the same resource or keyed in strings with errors to search for resources. On the other hand, the 'soft evidence' and ethnographic observation (participation in the discussion online and offline, forum, quality of tasks and final questionnaire) show, instead, a very involved, motivated, personalised and creative group of teachers who explored and critically discussed resources (for teaching or professional improvement), and provided useful remarks and suggestions for platform improvement such as pre-designed categorisation of resources, improved group design, and system documentation. Their suggestions were so relevant that we are currently implementing new features in the system: better search categorisation, a tagging 
system suited to the professional community of teachers, and My resources as a space that functions as a personalised laboratory and sandbox.

The difficulties with handling platform functionalities, which resulted in limited $\log$ data, were due to the general low level of digital skills and lack of experience as members of a professional online community. Practical difficulties were overcome thanks to the high level of motivation and involvement. The platform design will profit from the teachers' constructive and professional feedback.

\section{Concluding remarks and further developments}

The two-fold aims of the study were met beyond expectations: the experienced teachers who participated in the workshop confirmed the relevance of professional development through online collaboration in a community for professional development. Experienced teachers gained confidence in digital skills, in their professional competence, and actively contributed to improving the system design and the use of the platform. The participants also decided to organise teachertraining meetings in their different schools to share the experience and the expertise they acquired during the workshop. Thus, these experienced teachers have become teacher educators and will promote digital and professional competence through the online community.

Research and practice on the YELL/TELL platform and community are ongoing; we aim to promote internationally this expanding teacher community.

\section{References}

Abel, F., Marenzi, I., Nejdl, W., \& Zerr, S. (2009). Sharing distributed resources in LearnWeb2.0. In U. Cress, V. Dimitrova, M. Specht (Eds), Learning in the synergy of multiple disciplines, 5794, 154-159. https://doi.org/10.1007/978-3-642-04636-0

Bortoluzzi, M., \& Marenzi I. (2014). YELLing for collaborative learning in teacher education: users' voices in the social platform LearnWeb2.0. IJSMILE, 2(2), 182-198. https://doi. org/10.1504/IJSMILE.2014.063402

Cope, B. and Kalantzis, M. (2009). Multiliteracies: new literacies, new learning. Pedagogies: An International Journal, 4(3), 164-195. https://doi.org/10.1080/15544800903076044

Edge, J. (2011). The reflexive teacher educator in TESOL. London: Routledge.

Marenzi, I. (2014). Multiliteracies and e-learning 2.0. Foreign language pedagogy content-and learner-oriented (Vol. 28). Frankfurt am Main: Peter Lang. 
Marenzi, I., \& Zerr S. (2012). Multiliteracies and active learning in CLIL: the development of LearnWeb2.0. IEEE Trans. Learning Technologies (TLT), 5(4), 336-348. https://doi. org/10.1109/TLT.2012.14

Mirijamdotter, A., Somerville, M. M., \& Holst, M. (2006). An interactive and iterative evaluation approach for creating collaborative learning environments. EJISE, 9(2), 83-92.

Vuorikari, R. et al. (2012). Teacher networks. Today's and tomorrow's challenges and opportunities for the teaching profession. Brussels, Belgium: European Schoolnet.

Wang, F., \& Hannafin, M. J. (2005). Design-based research and technology-enhanced learning environments. ETR\&D, Wilson, 53(4), 5-23. https://doi.org/10.1007/BF02504682 


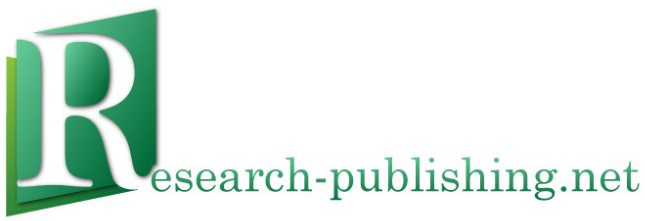

Published by Research-publishing.net, not-for-profit association Dublin, Ireland; Voillans, France, info@research-publishing.net

(C) 2016 by Editors (collective work)

(C) 2016 by Authors (individual work)

\section{CALL communities and culture - short papers from EUROCALL 2016 Edited by Salomi Papadima-Sophocleous, Linda Bradley, and Sylvie Thouësny}

Rights: All articles in this collection are published under the Attribution-NonCommercial -NoDerivatives 4.0 International (CC BY-NC-ND 4.0) licence. Under this licence, the contents are freely available online as PDF files (https://doi. org/10.14705/rpnet.2016.EUROCALL2016.9781908416445) for anybody to read, download, copy, and redistribute provided that the author(s), editorial team, and publisher are properly cited. Commercial use and derivative works are, however, not permitted.

\section{(9) $\Theta \Theta$}

Disclaimer: Research-publishing.net does not take any responsibility for the content of the pages written by the authors of this book. The authors have recognised that the work described was not published before, or that it is not under consideration for publication elsewhere. While the information in this book are believed to be true and accurate on the date of its going to press, neither the editorial team, nor the publisher can accept any legal responsibility for any errors or omissions that may be made. The publisher makes no warranty, expressed or implied, with respect to the material contained herein. While Research-publishing.net is committed to publishing works of integrity, the words are the authors' alone.

Trademark notice: product or corporate names may be trademarks or registered trademarks, and are used only for identification and explanation without intent to infringe.

Copyrighted material: every effort has been made by the editorial team to trace copyright holders and to obtain their permission for the use of copyrighted material in this book. In the event of errors or omissions, please notify the publisher of any corrections that will need to be incorporated in future editions of this book.

Typeset by Research-publishing.net

Cover design by (C) Easy Conferences, info@easyconferences.eu,www.easyconferences.eu

Cover layout by (c) Raphaël Savina (raphael@savina.net)

Photo "bridge" on cover by (C) Andriy Markov/Shutterstock

Photo "frog" on cover by (C) Fany Savina (fany.savina@gmail.com)

Fonts used are licensed under a SIL Open Font License

ISBN13: 978-1-908416-43-8 (Paperback - Print on demand, black and white)

Print on demand technology is a high-quality, innovative and ecological printing method; with which the book is never 'out of stock' or 'out of print'.

ISBN13: 978-1-908416-44-5 (Ebook, PDF, colour)

ISBN13: 978-1-908416-45-2 (Ebook, EPUB, colour)

Legal deposit, Ireland: The National Library of Ireland, The Library of Trinity College, The Library of the University of Limerick, The Library of Dublin City University, The Library of NUI Cork, The Library of NUI Maynooth, The Library of University College Dublin, The Library of NUI Galway.

Legal deposit, United Kingdom: The British Library.

British Library Cataloguing-in-Publication Data.

A cataloguing record for this book is available from the British Library.

Legal deposit, France: Bibliothèque Nationale de France - Dépôt légal: décembre 2016. 